The influence of cost of quality on the performance of food manufacturing companies: an empirical study

\begin{tabular}{|r|l|}
\hline Journal: & The TQM Journal \\
\hline Manuscript ID & TQM-01-2021-0026.R2 \\
\hline Manuscript Type: & Research Paper \\
\hline Keywords: & $\begin{array}{l}\text { Quality costs, Total Quality Management, Food Industry, Company } \\
\text { Performance }\end{array}$ \\
\hline \multicolumn{2}{|l}{} \\
\hline
\end{tabular}

\title{
SCHOLARONE \\ Manuscripts
}




\title{
The influence of cost of quality on the performance of food manufacturing companies: an empirical study
}

\begin{abstract}
Purpose: Due to the ever-increasing competitive and complex business environments, food manufacturing companies have to maintain high-quality products while simultaneously minimizing customers' costs. Cost of quality (COQ) plays a crucial role in enhancing companies' efficiency and reducing expenditures that can contribute to companies' competitive performance. This paper investigates the underlying relationship between the level of COQ practices adoption (prevention, appraisal, internal, and external failure costs) and organizational performance in Palestinian Food Manufacturing Companies (PFMC).
\end{abstract}

Design/Methodology/Approach: A quantitative research methodology using a structured questionnaire collected data from 119 PFMC. Partial least squares structural equation modeling was used to analyze collected data.

Findings: Results indicated that COQ adoption has a significant positive effect on the organizational performance of PFMC. Besides, prevention, external, and internal failure costs were all associated with a positive impact on organizational performance of PFMC, whereas appraisal cost did not affect organizational performance.

Originality: This study is considered one of the first studies to investigate COQ practices' effect on organizational performance in food manufacturing companies in a developing country context. Thus, it adds significant value to literature responding to calls to tackle competitiveness issues in current complex business environments.

Keywords: Cost of quality, quality costing system, TQM, food manufacturing, developing country, organizational performance, Palestine.

\section{Introduction}

Business organizations face competitive and complex circumstances because of the rapid growth of technology and the changing socio-economic environment (Psomas et al., 2018). Customers have become smarter, and thus acquiring new customers or maintaining existing ones has become a more significant challenge for most companies (Alglawe et al., 2017). 
This raises some questions about the extent to which companies can keep high-quality products and services with low costs (Ayach et al., 2019). Therefore, companies invest heavily in quality and work on continuous improvement initiatives to ensure that quality meets customer requirements and enhance new customer confidence (Glogovac and Filipovic, 2018). One of the most used approaches in organizations to achieve high quality products and services is the Total Quality Management (TQM) (Kefari et al., 2016). TQM philosophy, which the managers seek to create in the business environment, enables companies to produce flawless products and services based on continuous improvement coupled with a performance measurement system (Herzallah et al., 2017). In fact, increasing number of manufacturing organizations viewed TQM as an integrated approach for problem-solving technique and process improvement. This would imply that TQM is utilized for increasing internal and external customer satisfaction, while at the same time reducing quality costs (Hung and Sung, 2011; Saleh et al., 2018). However, companies' commitment or non-commitment to adopt TQM practices leads to so-called quality costs (Elyazid, 2016). Cost of quality (COQ) has four major categorizations: prevention, appraisal, internal and external failure costs. These categorizations are crucial for identifying the extent to which organizational resources are consumed by activities that leverage the quality of products and services and prevent poor quality (Kefari et al., 2016; Ghanem, 2018). However, Chatzipetrou and Moschidis (2017) confirmed that COQ practices are not well appreciated in food manufacturing companies, and that further analysis of their impact on food and beverages manufacturing organizations performance is much needed. In addition, Kefari et al. (2016) in their study of Tunisian food manufacturing sector asserted that formal application of COQ practices is quite rare due to lack of knowledge about their financial consequences and their benefits to organizational performance. This would mean that developing COQ systems by food manufacturers can provide information about financial returns of their quality programs (Omar and Murgan, 2014). In fact, the literature shows that very little is known about quality costing systems implementation and COQ practices in the food manufacturing sector in developing countries contexts (Omurgonulsen, 2009; Rahmat et al., 2016). Nevertheless, food manufacturers in developing countries need to adapt to developed countries food quality standards by following rigorous quality systems to continue trading with major companies 
and retailers (Masri and Jaaron, 2017). On top of this, food manufacturing organizations, in developed and developing countries alike, need to accommodate ever increasing demands from retailers (i.e., customers) for shorter delivery times, reduced prices, and improved food safety measures. These resemble powerful global challenges that force manufacturing industry to keep improving quality management techniques to remain profitable and competitive (Costa et al., 2018). Emanating from this, this paper examines the underlying relationship between the level of COQ practices adoption (prevention, appraisal, internal, and external failure costs) and organizational performance in PFMC. In the case of PFMC, there is almost no evidence in the quality management literature of previous empirical studies that explores COQ practices or costing systems, which gives this study more prominence.

The PFMC is one of Palestine's emerging industries and plays a major role in attracting investments in this industry and contributing about $4.8 \%$ to the GDP (PIPA, 2017). Conducting such studies in developing country context, especially in difficult and challenging environments like Palestine, is not unproblematic. Dual environmental legislations dominate the manufacturing organizations in Palestine: Palestinian National Authority (PNA) Law and Israeli Authorities Law; these laws are applied in the Occupied Palestinian Territories (OPT), where the vast majority of Palestinian manufacturers are placed. The OPT's unique situation results from using these Israeli laws on Palestine's internal policies, obliging manufacturers to abide by Israeli environmental policies alongside those of PNA (Zaid et al., 2018). This study is considered one of the first studies to investigate COQ practices' effect on organizational performance in food manufacturing companies in a developing country context. Thus, it adds significant value to literature responding to calls to tackle competitiveness issues in current complex business environments.

In keeping with its aims, the article is structured as follows: section two illustrates the concept of COQ and provides the research background on COQ and organizational performance, followed by section three which presents the research methodology. Next, data analysis and results are presented in section four. Then, discussion and conclusions are provided in section five, before presenting the research limitations and future research work in section six. 


\section{Theoretical foundation and hypothesis development}

\subsection{Characterizing $\mathrm{COQ}$}

Quality management has recently become a top priority for any company seeking to raise its performance and achieve success (Mata-Lima et al., 2016). It is the high quality that customers demand and the low price that attracts them and enables companies to surpass the competition (Ayash et al., 2019). Therefore, quality improvement programs are necessary for any business enterprise to flourish to improve the customer base (Sailaja et al., 2015). Total Quality Management (TQM) is described as an enterprise-wide management philosophy to improve organizational management that underlines the need to meet customer needs and get things correct first-time (Bajaj et al., 2018). It is an integrated approach for improving product and service quality, increase production, and thus improve profitability (Iqbal and Asrar ul-Haq, 2018). Still, customer satisfaction and continuous improvement remain crucial elements in supporting the TQM philosophy (AbuMahfouz, 2019). However, TQM philosophy depends largely on employees' practices and attitudes backed up by a quality costing system to evaluate performance (Djekic et al., 2014; Pattanayak et al., 2019).

COQ dates to Juran and Feigenbaum in the 1950s. They defined it as expenditures related to efforts and deficiencies related to quality. In other words, the cost is related to preventing, detecting, and correcting defective work (Farooq et al., 2017). However, there is no general agreement on a single broad definition of COQ; therefore, there are various definitions from several different domains (Elyazid, 2016). COQ is those expenses incurred by an organization to achieve and maintain good quality by eliminating causes of poor quality. This elimination of causes of poor quality will attain the highest level of customer satisfaction (Dan, 2017). According to Chatzipetrou and Moschidi (2016), COQ includes the cost of all the company's efforts to provide a product that can meet the customers' needs. Djekic et al. (2014) considered COQ to be an indicator of achievement or lack of quality and has proven to be useful as a comprehensive measure of organizational performance. On the other hand, Ghanem (2018) explain that it is widely accepted to classify these costs as conformance and non-conformance costs. This view of COQ classification was 
supported by the work of Omar and Murgan (2014). At a more subtle level, Juran (1951) and Feigenbaum (1956) classified the COQ into four main categories that will be followed in this research:

- Prevention costs: these are the costs invested in ensuring quality requirements will be met (Ayach et al., 2019). Its activities include cost of implementing and controlling the total quality control system and quality improvement programs (Farooq et al., 2017). They are also composed of quality planning, marketing, and designing development for products, purchasing, customer analysis, workforce development and training, and system development (Lari and Asllani, 2013).

- Appraisal cots: these are incurred by conducting a measurement, evaluation, or audit to ensure quality consistency. These costs include first-time inspection, checking, process or service audits, testing, calibration of measuring and test equipment, receipt inspection, and supplier surveillance (Khozein et al., 2013).

- Internal failure costs: these costs are related to activities conducted to deal with products that do not meet quality requirements before reaching the customer (Pattanayak et al., 2019). These include re-work or correction costs, scrap overtime costs to cover production losses, and re-inspection costs (Alglawe et al., 2017).

- External failure costs: they occur when defects are delivered to the customer mistakenly (Ahmad et al., 2015). External failure costs increase as the number of defective units delivered to customers increase (Chopra and Singh, 2015). They include complaints costs in warranty, product liability costs, and loss of sales costs (Chatzipetro and Moschidis, 2017).

The above classification led to the formation of the PAF model. It is the most basic and most normally used cost-quality analysis model (Ayach et al., 2019). It is widely used in manufacturing because of its straightforward interpretation, and its components can be easily and directly measured (Farooq et al., 2017; Plewa et al., 2016; Silaga et al., 2015). The PAF model's basic assumptions are that investment in prevention and evaluation activities will reduce failure costs and that further investment in prevention activities will reduce evaluation costs (Glogovac and Filipovic, 2017). Moreover, Snieska et al. (2013) 
emphasize that for companies to gain a competitive advantage, they should assess the costs of prevention, evaluation, internal, and external failures. Today's priority is to provide customers with the highest quality and best price; this can be achieved by determining optimal quality costs (Sainis, 2018).

\subsection{COQ and organizational performance}

Today as global competition remains to grow rigorously, organizations must support their competitiveness on costs and ensure that their products and services quality match their clients expectations (Dan, 2017). Ghasghaee and Fathollahi (2014) discussed that the increasing investment in prevention costs could reduce external failure costs, which can ultimately enrich client satisfaction levels. Additionally, Ebrahimi and Sadeghi (2013) explained that successful implementation of quality management requires an effective COQ system as this can lead to significant improvements in organizational performance. This is what Herzallah et al. (2014) confirmed in their research that showed that TQM practices, including $\mathrm{COQ}$, are indirectly related to enhanced financial performance. Recently, Shafiq et al. (2019) argued that TQM practices can enhance financial and nonfinancial results for organizations by providing empirical evidence from the textile sector in Pakistan. At a more subtle level, Kerfai et al. (2016) settled that companies with COQ systems encounter fewer internal and external failures than those with no COQ system. Also, they found that these companies invest more in prevention and appraisal actions than others. Furthermore, authors discovered that COQ adoption has positive outcomes on the company's overall performance. Similarly, Pattanayak et al. (2019) asserted that the prerequisite to improve the company's poor performance is a complete and effective system for tracking COQ. The work of Lari and Asllani (2013) provided an evidence for the importance of COQ systems for organizational performance. They explained that COQ system allows an organization to have a metric through which monitoring and, thus, controlling its processes and managerial activities become possible. This was confirmed by Diefenbach et al. (2018) who found that a cost management control system, such as COQ system, has a significant effect on organizational cost efficiency and overall organizational performance. In a study by Guinot et al. (2016), North American automobile manufacturers attributed positive impact on the present worth of a new product launch 
Also, Psomas et al. (2018) study on COQ measurement in Greek food manufacturing sector explained the importance of prevention costs. Authors posited that by increasing the costs of prevention, the cost of internal and external failure will be shrunk. This will enable an organization to be more efficient and able to satisfy its customers. Thus, it directly and positively affects organizational performance. According to Bayram and Ünğan (2020), prevention costs of quality resembles organizational efforts to improve processes before problems occur, and therefore can enhance organizational learning capabilities by turning learning opportunities into actions that foster organizational performance. In fact, the work of Psomas et al. (2018) also suggested that organization that decided to invest in prevention costs of quality can be more competitive in the market due to reduced accidents and wasted resources. Moreover, Ayach et al. (2019) believed that investments in prevention and appraisal activities lower the total quality cost. Besides, Starčević et al. (2015) explained that the companies that set quality costs provide higher quality services than competitors that do not measure their quality costs. Their study concluded that this can, eventually, lead to a significantly higher average rate of financial performance. Teli et al. (2013) illustrated that it is vital to find and permanently eliminate root causes of production failures through 
statistical quality control methods coupled with COQ practices. Proper analysis of cause and effect can reduce the real cost of poor quality (COPQ). So, prevention activities lead to a lower COPQ ratio for these new processes and products. Based on this discussion, the following hypothesis is proposed:

\section{H1.1: There is a significant positive relationship between prevention costs practices and organizational performance of PFMC.}

Regarding the importance of appraisal costs for organizational growth, Shin et al. (2018) outlined that investing in appraisal costs, such as in-process inspection, equipment testing, and laboratory testing, may dramatically reduce cost of scrap, repair, and overall waste. Understandably, this will have direct effects on reducing customer complaints and loss of goodwill. Likewise, Akenbor (2014) indicated that appraisal costs are strongly attached to customer satisfaction levels. It has been explained that the increase in quality nonconformance cost leads to an immediate decreased in customer satisfaction. So, it is suggested that companies' investment in quality appraisal activities, such as quality planning, preventive maintenance, material, equipment, and facilities inspection, is necessary to reduce internal and external failure costs and to increase customer satisfaction. In the same vein, a study by Kerfai et al. (2016) on quality costing in Tunisian manufacturing organizations illustrated that quality appraisal activities such as preproduction verification, product testing, receiving inspection, and the use of external auditors all have positive consequences on customer satisfaction, sales growth, and other aspects of the organizational performance. Further insights were discerned from the work of Larry and Aslani (2013) who found that preventive quality measures such as preexamining materials and equipment have tendency to enhancing operational performance. According to Sturm et al. (2019), although the elimination of appraisal cost as part of COQ system in manufacturing organizations does not exist, their impact on processes performance is significant for organizations that seek to improve their competitiveness. Moreover, Reema (2014) emphasized the importance of not cutting appraisal costs by quality managers, as this will ultimately lead to an increase in failure occurrences that could damage the company's reputation. Based on these arguments, the following hypothesis can be formulated: 


\section{H1.2: There is a significant positive relationship between appraisal costs practices and organizational performance of PFMC.}

On the other hand, Psomas et al. (2018) highlighted the importance of properly allocating resources to improve the balance between the COQ dimensions in favor of the prevention and appraisal cost. In doing so, the cost of internal and external failure will be reduced, which will make the foodstuff company more efficient and satisfy its customers. Additionally, Chopra and Singh (2015) demonstrated how decreasing internal and external failure costs would lead to better organizational performance. Furthermore, Lari and Asllani (2013) presented that greater attention is required in the design development process to prevent reworks and know the importance of internal and external failure costs. Similarly, the work of Cermakova and Bris (2017) conducted an action research project to implement COQ system in a Czech manufacturing company. They concluded that the greatest potential for creating improvements in the overall performance was hidden in the internal and external failure costs of the COQ system. Furthermore, Kerfai et al. (2016) also concluded that implementing a COQ system helps the company control costs better and improve performance by promoting actions that reduce internal and external failures. Ghanem (2018) indicated that external failure costs are the most critical COQ element because these costs are hidden cost, and it is difficult to estimate. However, Guinot et al. (2017) recognized that internal and external failure costs are extremely useful in improving internal performance of organizations, as they can be used as indicator to reflect adequacy of quality appraisal and prevention activities. Moreover, Ayach et al. (2019) stated that after implementing COQ system, reduced customer complaints, rework and scrap, warranty expenses, failure costs, and increased sales volume were observed. Likewise, Akenbor (2014) indicated that the quality cost is significant to customer satisfaction by eliminating internal and external failure costs for customers' satisfaction with health products. Consequently, the following two hypotheses are formulated:

H1.3: There is a negative relationship between external failure costs and organizational performance of PFMC.

H1.4: There is a negative relationship between internal failure costs and organizational performance of PFMC. 
Glogovac and Filipovic (2018) demonstrated a strong, statistically significant relationship between the organization's age and COQ application. Companies operating for more than ten years indicate a higher level of quality cost management. Also, Prickett and Rapley (2001) confirmed that the level of quality cost management depends much on the company's essential demographic characteristics, such as business activity, origin, business market, environment competitiveness, and age as the characteristics of its management systems. These contextual factors of effect of age on COQ practices implementation level drove authors intention in this study to test for the potential moderating impact of age of organizations on COQ practices in PFMC. Therefore, the following hypothesis is proposed:

\section{H2: Age of PFMC moderates the relationship between COQ application and Organizational performance.}

Moreover, Chopra and Singh (2015) asserted that much sufficient quality and productivity improvement tools generally find no place in small and medium-sized enterprises due to a lack of knowledge and resources. Whereas Starcevic et al. (2015) confirmed the fact that as large companies have more resources than small and medium-sized companies, it is assumed that they will primarily quantify quality costs. Additionally, Ayach et al. (2019) found that the quality cost categories depend on the firm's structure, technology, and size. They emphasized that the implementation of COQ system depends on a company's essential features, for instance, business activity, size, and the possession of quality certifications. As well, Chatzipetrou and Moschidis (2017) approved that the way companies observe quality costs proved to be highly dependent on their size. While Trehan et al. (2015) discussed that the increasing use of quality costing increases with the increase in the organizational size. Due to all this, the following hypothesis is proposed in this study:

H3: Size of PFMC moderates the relationship between COQ application and organizational performance.

Based on the research hypotheses formulated above, a conceptual framework was formed. The framework seeks to identify the underlying relationship between the level of COQ 
practices adoption (prevention, appraisal, internal, and external failure costs) and organizational performance in the context of the PFMC. In this paper, the authors refer to organizational performance as indicators related to financial, customer, internal business, and learning and growth performance. Also, the framework seeks to find out if age and size of PFMC can moderate the relationship between COQ practices and organizational performance. This conceptual framework is shown in Figure 1.

[Figure 1: Conceptual research framework]

\section{Methodology}

\subsection{Measurement instrument}

This research adopted a quantitative research methodology using a survey. The survey was developed based on a literature review of similar studies. The survey contained four parts. The first part covered demographic information of respondents and contained 10 items. The second part estimated to what extent companies use COQ practices and contained 22 items, while the third part provided items that assess organizational performance indicators with a total of 20 items. Finally, in the fourth part, the respondent was left with a note box to provide any other remarks or notes that the respondent might find necessary. For the measurement of COQ constructs, a 1-5 Likert scale was used. The respondents were required to respond to the statements that most closely represent their observations about their company's management practices. Similarly, the Likert scale was used for the items that measured the organization's performance. Each respondent was required to respond to the statements based on their company's performance over the previous fiscal year. For the Likert scale, the use of 1 reflected "not at all" practice, whereas 5 reflected "to a very great extent" practice. To maintain content validity of the survey (Saunders et al., 2016), five expert academics and two senior practitioners reviewed the survey items. It was deemed that the survey was clear enough and contained all items required for each section.

\subsection{Population, sample size, and respondents}

This study was conducted among the PFMC population. According to PFI (2017), the total number of PFMC in this sector is 283 companies. However, a criterion was used to only target those companies that are registered and licensed by Palestinian Authorities, has a 
quality department or a quality officer with announces quality policy, and a human resources department or function. After applying this selection criterion, 167 PFMC were found to match this criterion. The sample size was calculated using the Thompson formula with a confidence interval of $95 \%$ and an error margin of 5\% (Thompson, 2012). It was found that the minimum required sample is 117 . The survey was sent to all qualified companies in the population (i.e., 167) in person and over email after contacting the companies by email and telephone. One survey was sought to be collected from each of the sample PFMC after being completed by either the general manager, quality manager, senior quality engineer, or HR manager with quality responsibilities. Over a period of five months, the total number of completed surveys retrieved reached 121. After the outlier's test, two were deleted, leaving 119 valid, complete, and usable forms. This represents a response rate of $72.4 \%$. Figure 2 shows the distribution of companies sample according to food product type. And Table 1 provides details of participating PFMC in terms of the demographic of the sample.

[Figure 2: Distribution of companies sample according to business type]

[Table 1. Demographics of the sample]

\section{Data analysis and results}

Data collected from the survey were analyzed using Partial Least Square Structural Equation Modelling (PLS-SEM) technique; a multivariate statistical framework used to model complex relationships between directly and latent variables (Hair et al., 2014). The study's essential focal point is to anticipate and clarify the primary target constructs or identify the critical driver constructs (Rigdon, 2012). PLS-SEM will be used as a vital analysis method for the survey results to study the correlations between this study's hypotheses (Wong, 2013). PLS-SEM is suggested when a structural model is complex and for the phenomenon that is abstract and not directly observable (Hair et al., 2017).

\subsection{Assessment of measurement model reliability and validity}


The measurement model's internal consistency is assessed using composite reliability (CR). The CR varies from 0 to 1 , with higher values indicating higher levels of reliability. It is generally interpreted in the same way as Cronbach's alpha. Specifically, CR values above 0.60 are acceptable in exploratory research (Sarstedt et al., 2014). Table 2 shows that all Cronbach's alpha and CR values for the tested research constructs are acceptable.

[Table 2. Cronbach's Alpha and composite reliability values]

The convergent validity $(\mathrm{CV})$ is a measure that predicts the extent to which the questions are close and compatible with each other (Hair et al., 2017), and measures using Average Variance Extracted (AVE) value. The AVE value of (0.5) or higher designates that a latent variable can explain half or more than half of its indicators' variance on average. Table 3 shows results of the measurement model convergent validity. All AVE values are above the value of 0.5 which are considered sufficient (Fornell and Larcker, 1981; Hair et al., 2014).

[Table 3. Main results - measurement model]

A common rule of thumb is that the standardized outer loadings should be 0.708 or higher (Henseler et al.,2016). However, values of 0.4 or higher is also acceptable when conducting an exploratory study like the current study (Henseler et al., 2016). The results generated using SmartPLS 3 have values greater than 0.4 for all the loadings and hence can be accepted. As for the discriminant validity, Fornell-larcker (1981) criterion suggested that each construct's AVE can be compared with the squared inter-construct correlation (as a measure of shared variance) of that same construct. All other reflectively measured constructs in the structural model; the shared variance for all model constructs should not be larger than their AVEs (Hair et al., 2017). The summary of the test results is presented in Table 4.

[Table 4. Fornell-Larcker's criterion test summery]

Based on Table 3, appraisal cost's AVE is found to be (0.697). Hence, its square root becomes (0.835); this is larger than the correlation values in the column and row of 
appraisal costs provided in Table 4. A similar finding is observed for all other variables shown in Table 4. The results, hence, indicate that discriminant validity is well established.

COQ consists of four components, and several practices measure each element as per the literature review. Figure 3 shows SmartPLS generated evaluation of the measurement model.

[Figure 3: Measurement model Evaluation as generated by SmartPLS]

\section{2. $\quad$ Assessment of structural Model}

Assessing the latent variable's path coefficients is used to validate the proposed hypotheses and the structural model (Hair et al., 2011). By examining the path coefficient, a scholar can predict the strength of the connection between two latent variables. The scholar should test the path coefficients, arithmetical sign, extent, and centrality to inspect the relationship between two latent variables. As per Hair et al. (2016), the path coefficients ought to surpass 0.100 to represent a specific effect inside the model and be significant at any rate at the 0.05 value. Standard Beta, standard error, T-Value, and P-Value are illustrated in Table 5, and Figure 4 shows path's P-Values for the blindfolding model generated by Smart-PLS.

[Table 5. Path Coefficients - Summary of Hypotheses Testing "Direct relationship"]

The results show that four hypotheses were supported (i.e., H1, H.1.1, H1.3, and H1.4). However, the other three hypotheses (i.e., H1.2, H2, and H3) were not supported.

[Figure 4: P-values generated by SmartPLS]

Indicators of model fit enable judging how well a hypothesized model structure fits the empirical data and helps identify model misspecifications (Hair et al., 2016). One of the earliest proposed indices is a goodness-of-fit index (GOF) as an operational solution. It is the geometric mean of both average variances extracted (AVE) and the average of $\mathrm{R}^{2}$ of 
the endogenous variables (Hair et al.,2016). The purpose of GOF is to account for the study model at both levels, namely measurement, and structural model, focusing on the model's overall performance (Henseler and Sarstedt, 2013). Chin's (2010) calculation formula of GOF is as follow:

$\mathrm{GOF}=\sqrt{\left(R^{2} \times A V E\right)}=0.682$

The criteria to verify whether GOF values are no fit, small, medium, or large have been given by Wetzels (2009). Table 6 below shows these criteria:

[Table 6. The criteria of GOF]

Based on Table 6 and the value of the GOF (0.682), it is evident that the GOF model of this study is large enough to be considered as having sufficient global PLS model validity.

\section{Discussion and conclusions}

This main aim of this research was to investigate the underlying relationship between the level of COQ practices adoption (prevention, appraisal, internal, and external failure costs) and organizational performance in PFMC. To the best of the authors knowledge, this study is the first to investigate the effect of COQ practices on organizational performance in food manufacturing companies in a developing country context, thus adding great value to literature responding to calls to tackle competitiveness issues in current complex business environments. The overall hypotheses testing results achieved through the PLS-SEM technique have proven a positive and significant relationship between COQ and organizational performance $(\beta=0.826, \mathrm{t}=4.459, \mathrm{p}=0.000)$. This result is in line with several previous studies. For example, Ghanem (2018) confirms the validity of the causal relationship between the COQ and improving the organizations' competitive advantages by enhancing all performance tools. Moreover, Kerfai et al. (2016) found that COQ has the potential to support managers in promoting procedures that help the company control costs better, increase profit, and improve performance. This result also coheres with Modhiya and Desai's (2016) findings, stating that after COQ implementation, customer complaint reduction can be achieved along with scrap and reword numbers drop. Besides, Pattanayak et al. (2019) asserted that the prerequisite to improve the company's poor performance is a 
complete and sensitive costing system for COQ. Furthermore, Moschidis et al. (2018) found that quality costing sets the priorities for the necessary corrective actions, helping companies focus upon the areas that need improvement.

The results have also shown a significant and positive relationship between prevention costs and organizational performance of PFMC. This can be explained by the fact that through increasing the costs of prevention, the cost of internal and external failure will be reduced. This will then lead companies to improve quality and competitiveness, which in turn positively affects customer satisfaction levels and brand image and will lead to performance improvement. However, this result is in congruence with Psomas et al. (2018) who explained the importance of prevention costs for companies' competitive advantage and overall performance through improved product quality. Moreover, Ayach et al. (2019) believed that investments in prevention activities lower the total quality cost. In fact, prevention costs in this research are believed to have positively affected PFMC organizational performance due to its focus on employee's training and development that raises employees' skills and innovation. This was supported by Kerfai et al. (2016), who linked prevention cost activities of employees training and development programs with improving learning and growth performance perspective, which is one of the organizational performance indicators. However, the appraisal costs have been found not to influence organizational performance of PFMC. This result seems to contradict with what was discussed in several previous studies such as Ahmad et al. (2015), Kerfai et al. (2016), and Ayach et al. (2019). These authors explained the importance of appraisal costs in segregating non-conforming products from those confirming products, which ensures delivery of good products only to customers and, therefore, retaining satisfied customers necessary for improved organizational sales and market share. They also explained the crucial role of appraisal costs in identifying whether activities are done properly or not by employees. However, this contradictory result from the PFMC can be explained by the fact that PFMC are top-down businesses where employees have little freedom to change processes causing errors. Thus, appraisal costs at PFMC, which reflects inspection of products, remove bad products but does not remove the cause of the error. This was confirmed by Sharif et al. (2018) in their study of drivers for cost of quality in PFMC, where they explained that PFMC inspect raw materials, do necessary measurements and 
testing, and recruit enough inspection staff, but apply mechanistic structure that does not allow employees to redesign operations for error source removals. Similarly, Purushothama (2012) asserted that inspection activities cannot improve internal operational performance of organizations but can only sort out some of the bad products.

The results also illustrated a negative relationship between internal and external failure costs and organizational performance. This was in line with Chopra and Singh (2015) who demonstrated that increasing internal and external failure costs is an indicator of a significant increase in number of resources consumed and profits lost by organizations. They added that decreasing these costs is a direct measure for improving organizational performance. Furthermore, Kerfai et al. (2016) concluded that improving organizational performance is strongly linked with actions that reduce internal and external failures such as scrap, absenteeism, and customer complaints. This result also coheres with the results found by Akenbor (2014) who indicated that decreasing internal and external failure costs is a result of an intelligent enhancement in the adoption of error prevention activities, which can immensely enhance organizational performance.

In this study, the differences in the level of COQ are observed regarding the companies' size and age. It was found that size and age do not have any moderating effect between COQ practices and organizational performance in PFMC $(\mathrm{p}>0.05)$. This was unlike findings reported in previous research where company size and age are essential for the COQ management level (Chatzipetrou and Moschidis, 2017; Chopra and Singh, 2015; Glogovac and Filipovic, 2018). This is because majority of PFMC are family businesses where general managers are family members who have high levels of attachment and commitment to organizational success (Abuznaid, 2014). This would imply that any quality management initiatives, such as the application of COQ practices, are supported and are pledged to organization success.

The results reported in this study have some prominent insights for managers and researchers. First, it is deducted that managers should invest more in prevention costs such as quality planning, customer analysis, and employees' training and development. This can, eventually, allow managers to significantly reduce internal and external failure costs that can boost competitive advantage. Second, it is evident that managers should also invest 
more in re-work, scrape, and re-inspection practices as part of the internal failure costs and invest in practices that can improve customer complaints rates, product liability costs, and number of defects delivered to customers as part of the external failure costs. These measures, as shown in results, can significantly enhance organizational performance in similar business contexts. However, this study theorizes for the first time the COQ practices with organizational performance in food manufacturing sector in developing countries context. This linking articulates a structured process of learning about the practices that have the highest impact on organizational performance.

\section{Limitations and future research directions}

Although this study provides new insights on the underlying relationship between COQ practices adoption and organizational performance in developing countries context, it has some limitations that can pave the way for further future COQ research. The nature of food manufacturing companies is unique (Djekic et al., 2014) that makes generalizing the results to other sectors limited. Hence, future research may consider replicating this study in other manufacturing sectors in developing countries to investigate tested relationships. Also, future research may consider re-investigation of relationships tested in this study using longitudinal research design to capture the nature of organizational performance change over a longer period. Furthermore, this study collected data from PFMC managers and employees without the inclusion of customer and stakeholders' perspectives. It would be essential for future research to replicate this study by triangulating the results using customer and stakeholders' inputs on the level of organizational performance improvements. Finally, there is a need for future studies that can include other moderating variables, other than size and age, on the relationship between COQ practices and organizational performance such as financial strength and quality certification availability.

\section{$\underline{\text { References }}$}

Abu-Mahfouz, S. S. (2019). TQM Practices and Organizational Performance in the Manufacturing Sector in Jordan mediating role of HRM Practices and Innovation. Journal of Management and Operation Research, 1 (22), 1-12.

Abuznaid, S.A. (2014). Managing a Family Business in a Complex Environment: The Case of Palestine. International Journal of Business and Social Science, 5 (10), 187-196. 
Ahmad, S., Pesch, M. J., \& Gulati, R. (2015). Cost of quality: Lessons from toy recalls. Journal of International Business Research, 14(2), 1-14.

Alglawe, A., Schiffauerova, A., \& Kuzgunkaya, O. (2019). Analysing the cost of quality within a supply chain using system dynamics approach. Total Quality Management \& Business Excellence, 30(15-16), 1630-1653.

Altayeb, M. M., \& Alhasanat, M. B. (2014). Implementing total quality management (TQM) in the Palestinian construction industry. International Journal of Quality \& Reliability Management. 31(8):878-887.

Akenbor, C. O. (2014). An accounting reflection of quality cost and customer satisfaction of health products in Nigeria. Journal of Business and Retail Management Research, 8(2), 42-53.

Ayach, L., Anouar, A., \& Bouzziri, M. (2019). Quality cost management in Moroccan industrial companies: Empirical study. Journal of Industrial Engineering and Management, 12(1), 97-114.

Bajaj, S., Garg, R., \& Sethi, M. (2018). Total quality management: a critical literature review using Pareto analysis. International Journal of Productivity and Performance Management, 67 (1), 128-154.

Bayram, M. and Ünğan, M.C. (2020). The relationships between OHS prevention costs, OHSMS practices, employee satisfaction, OHS performance and accident costs. Total Quality Management \& Business Excellence, 31(11-12), 1325-1344.

Cermakova, C. and Bris, P. (2017). Managing the costs of quality in a Czech manufacturing company. Scientific Papers of the University of Pardubice. Series D, Faculty of Economics and Administration, 25(41), 6-18.

Chatzipetrou, E., \& Moschidis, O. (2017). An exploratory analysis of quality costing in Greek F\&B enterprises. The TQM Journal, 29(2), 324-341.

Chin W.W. (2010). How to Write Up and Report PLS Analyses. In: Esposito Vinzi V., Chin W., Henseler J., Wang H. (eds) Handbook of Partial Least Squares. Springer Handbooks of Computational Statistics. Springer, Berlin, Heidelberg, 655-690. https://doi.org/10.1007/978-3-540-32827-8_29

Chopra, A., \& Singh, B. J. (2015). Unleashing a decisive approach to manage quality costs through behavioural investigation. Business Process Management Journal., 21(6), 1206-1223.

Costa, L.B.M., Filho, M.G., Fredendall, L.D. \& Paredes, F.J.G. (2018). Lean, six sigma and lean six sigma in the food industry: A systematic literature review. Trends in Food Science \& Technology, 82, 122- 133.

Ćwiklicki, M. (2016). Understanding Management Concepts through Development of their Tool Box: The case of total quality management. Naše gospodarstvo/Our economy, 62(1), 56-62.

Dan.O. (2017). Cost of quality and organizational performance in sugar manufacturing firms in Kenya. University of Nairobi Digital Repository. Available from http://hdl.handle.net/11295/102941 [Accessed 27 December 2020].

Diefenbach, U., Wald, A. and Gleich, R. (2018). Between cost and benefit: investigating effects of cost management control systems on cost efficiency and organisational performance. Journal of Management Control, 29 (1), 63-89.

Dimitrantzou, C., Psomas, E. and Vouzas, F. (2020). Future research avenues of cost of quality: a systematic literature review. The TQM Journal, 32(6), 1599-1622. 
Djekic, I., Zaric, V., \& Tomic, J. (2014). Quality costs in a fruit processing company: a case study of a Serbian company. Quality Assurance and Safety of Crops \& Foods, 6(1), 95-103.

Ebrahimi, M. \& Sadeghi, M. (2013). Quality management and performance: An annotated review. International Journal of Production Research, 51(18), 5625-5643.

Elyazid, S. (2016). Performance Measurement: Quality, Cost, and Time Is New System: So Called Strategic Cost Management. Research Journal of Finance and Accounting, 7(17), 1-11.

Farooq, M. A., Kirchain, R., Novoa, H., \& Araujo, A. (2017). Cost of quality: Evaluating cost-quality trade-offs for inspection strategies of manufacturing processes. International Journal of Production Economics, 188, 156-166.

Fornell, C., \& Larcker, D. F. (1981). Structural equation models with unobservable variables and measurement error: Algebra and statistics. Journal of Marketing Research, 18(3), 382-388.

Ghanem, F. A. (2018) Cost of quality ad a tool to improve the Palestinian industrial organization competitive advantage. International Journal of business quantitative economics and applied management research, 4(11), 35-53.

Ghasghaee, E. K., \& Fathollahi, J. (2014). The relationship between cost, quality and financial performance of the company (with a case study of Tehran Stock Exchange). Indian Journal of Fundamental and Applied Life Sciences, 4(S4), 15751585.

Glogovac, M., \& Filipovic, J. (2018). Quality costs in practice and an analysis of the factors affecting quality cost management. Total Quality Management \& Business Excellence, 29(13-14), 1521-1544.

Guinot, J., Sinn, J.W., Badar, M.A. and Ulmer, J.M. (2017). Cost consequence of failure in failure mode and effect analysis. International Journal of Quality \& Reliability Management, 34(8), 1318-1342.

Guinot, J., Evans, D. and Badar, M.A. (2016). Cost of quality consideration following product launch in a present worth assessment. International Journal of Quality \& Reliability Management, 33(3), 399-413.

Hair Jr, J. F., Hult, G. T. M., Ringle, C., \& Sarstedt, M. (2016). A primer on partial least squares structural equation modeling (PLS-SEM). Thousand Oaks, California: Sage publications.

Hair, J. F., Ringle, C. M., \& Sarstedt, M. (2011). PLS-SEM: Indeed a silver bullet. Journal of Marketing theory and Practice, 19(2), 139-152.

Hair, J. F., Hult, G. T. M., Ringle, C. M., Sarstedt, M., \& Thiele, K. O. (2017). Mirror, mirror on the wall: a comparative evaluation of composite-based structural equation modeling methods. Journal of the Academy of Marketing Science, 45(5), 616-632.

Hair Jr, J. F., Sarstedt, M., Hopkins, L., \& Kuppelwieser, V. G. (2014). Partial least squares structural equation modeling (PLS-SEM). European business review, 26(2), 106121.

Henseler, J., Hubona, G., \& Ray, P. A. (2016). Using PLS path modeling in new technology research: updated guidelines. Industrial management $\&$ data systems, 116(1), 2-20.

Herzallah, A. M., Gutiérrez-Gutiérrez, L., \& Munoz Rosas, J. F. (2014). Total quality management practices, competitive strategies and financial performance: the case 
of the Palestinian industrial SMEs. Total Quality Management \& Business Excellence, 25(5-6), 635-649.

Hung, H.C. and Sung, M.H. (2011). Applying six sigma to manufacturing processes in the food industry to reduce quality cost. Scientific Research and Essays, 6(3), 580-591. doi: 10.5897/SRE10.823.

Iqbal, A., \& Asrar-ul-Haq, M. (2018). Establishing relationship between TQM practices and employee performance: The mediating role of change readiness. International Journal of Production Economics, 203, 62-68.

Kerfai, N., Ghadhab, B. B., \& Malouche, D. (2016). Performance measurement and quality costing in Tunisian manufacturing companies. The TQM Journal, 28(4), 588-596.

Khozein, A., Mohammadi, J., \& Abbasi Zarmehri, M. (2013). Cost of quality and quality optimization in manufacturing. European Online Journal of Natural and Social Sciences, $2(3$ (s)), 1070-1081.

Lari, A., \& Asllani, A. (2013). Quality cost management support system: an effective tool for organisational performance improvement. Total Quality Management \& Business Excellence, 24(3-4), 432-451.

Masri, H.A. \& Jaaron, A.A.M. (2017). Assessing green human resources management practices in Palestinian manufacturing context: An empirical study. Journal of Cleaner Production, 143, 474-489.

Mata-Lima, H., Morgado-Dias, F., Galuzzi da Silva, M.C., Alcântara, K. \& Almeida, J.A. (2016). A Systematic Framework for the Design and Implementation of a Quality Management Practice: The Case of a Consulting Engineering Company. Environmental Quality Management, 25(4), 49-61.

Modhiya, S. \& Desai, D. (2016). A review on cost of quality methodology and hidden costs in manufacturing industries. REST Journal on Emerging trends in Modelling \& Manufacturing, 2(4), 87-94.

Moschidis, O., Chatzipetrou, E., \& Tsiotras, G. (2018). Quality costing and quality management maturity in Greece: An exploratory multi-dimensional data analysis. International Journal of Productivity and Performance Management, 67(1), 171-191.

Omar, M. K. and Murgan, S. (2014). An improved model for the cost of quality. International Journal of Quality \& Reliability Management, 31(4), 395418. https://doi.org/10.1108/IJQRM-05-2012-0066

Omurgonulsen, M. (2009)'A research on the measurement of quality costs in the Turkish food manufacturing industry',Total Quality Management \& Business Excellence, 20(5), 547-562.

Palestinian Federation of Industries (PFI) (2017) The Current Status of Industrial Sector in Palestine. Available at: http://www.pfi.ps/Portals/_default/Reports/1.pdf [Accessed 23 September 2020].

Pattanayak, A.K., Prakash, A. \&Mohanty, R.P. (2019). Risk analysis of estimates for cost of quality in supply chain: a case study. Production Planning \& Control, 30(4), pp.299-314.

Palestinian Investment Promotion Agency (PIPA) (2017). Food and beverage industry. [online]. Available at: http://www.pipa.ps/page.php?id=1ab350y1749840Y1ab350 [Accessed 3 April 2020]. 
Plewa, M., Kaiser, G., \& Hartmann, E. (2016). Is quality still free? Empirical evidence on quality cost in modern manufacturing. International Journal of Quality \& Reliability Management. 33(9), 1270-1285.

Prickett, T. W., \& Rapley, C. W. (2001). Quality costing: A study of manufacturing organizations. Part 2: Main survey. Total Quality Management, 12(2), 211-222.

Psomas, E., Dimitrantzou, C., Vouzas, F., \& Bouranta, N. (2018). Cost of quality measurement in food manufacturing companies: the Greek case. International Journal of Productivity and Performance Management, 67(9),1882-1900

Purushothama, B. (2012). Costing and cost of quality. In: Purushothama, C. (eds.) Training and Development of Technical Staff in the Textile Industry. India: Woodhead Publishing India, 99-114.

Rahmat, S.; Cheong, C.B. \& Abd Hamid, M.S. (2016). Challenges of Developing Countries in Complying Quality and Enhancing Standards in Food Industries, Procedia - Social and Behavioral Sciences, 224, 445-451.

Rema, S. (2014). Modeling Cost of Quality in the Construction Industry A closer look at the Procurement Process using System Dynamics, Doctoral dissertation, Concordia University, Canada.

Rigdon, E.E. (2012). Rethinking partial least squares path modeling: In praise of simple methods. Long Range Planning, 45(5-6), 341-358.

Sainis, G. (2018). Characterising the Quality Journey of Total Quality Management in Relation to the Financial Performance of SMEs Under Crisis Conditions: the Case for Greece. Doctoral Dissertation, University of Hertfordshire, England.

Sailaja, A., Basak, P.C. \& Viswanadhan, K.G. (2015). Hidden costs of quality: Measurement \& Analysis. International Journal of Managing Value and Supply Chains, 6(2), 13-25.

Saleh, R.A., Sweis, R.J. and Mahmoud Saleh, F.I. (2018). Investigating the impact of hard total quality management practices on operational performance in manufacturing organizations: Evidence from Jordan. Benchmarking: An International Journal, 25(7), 2040-2064.

Sarstedt, M., Hair, J. F., Ringle, C. M., Thiele, K. O., \& Gudergan, S. P. (2016). Estimation issues with PLS and CBSEM: Where the bias lies!. Journal of Business Research, 69(10), 3998-4010.

Saunders, M., Lewis, P. \& Thornhill, A. (2016). Research methods for business students. Harlow, Essex: Pearson Education Limited.

Shafiq, M., Lasrado, F. \& Hafeez, K. (2019). The effect of TQM on organisational performance: empirical evidence from the textile sector of a developing country using SEM. Total Quality Management \& Business Excellence, 30(1-2), 31-52.

Shin, W.S.; Dahlgaard, J.J.; Dahlgaard-Park, S.M. and Kim, M.G. (2018). A Quality Scorecard for the era of Industry 4.0. Total Quality Management \& Business Excellence, 29(9-10), 959-976.

Snieška, V., Daunorienè, A. \& Žekevičienè, A. (2013). Hidden costs in the evaluation of quality failure costs. Engineering Economics, 24(3), 176-186.

Starčević, D.P., Mijoč, I. \& Mijoč, J. (2015). Quantification of quality costs: Impact on the quality products. Ekonomski pregled: mjesečnik Hrvatskog društva ekonomista Zagreb, 66(3), 231-251. 
Sturm, S., Kaiser, G., \& Hartmann, E. (2019). Long-run dynamics between cost of quality and quality performance dynamics. International Journal of Quality \& Reliability Management, 36(8), 1438-1453. doi:10.1108/IJQRM-05-2018- 0118

Teli, S.N., Majali, V.S., Bhushi, U.M. et al. (2013). Cost of Poor Quality Analysis for Automobile Industry: A Case Study. J. Inst. Eng. India Ser. 94, 373-384. https://doi.org/10.1007/s40032-013-0091-z

Thompson, S. K. (2012) Sampling. 3rd edn. New Jersey: Wiley Publishers and Sons.

Trehan, R., Sachdeva, A., \& Garg, R. K. (2015). A comprehensive review of cost of quality. VIVECHAN International Journal of Research, 6(1), 70-88.

Wetzels, M., Odekerken-Schröder, G., \& Van Oppen, C. (2009). Using PLS path modeling for assessing hierarchical construct models: Guidelines and empirical illustration. MIS quarterly, 33(1), 177-195.

Wong, K. (2013). Partial least squares structural equation modeling (PLS-SEM) techniques using SmartPLS. Marketing Bulletin, 24(1), 1-32

Zaid, A.A., Jaaron, A.A. \& Bon, A.T. (2018). The impact of green human resource management and green supply chain management practices on sustainable performance: An empirical study. Journal of Cleaner Production, 204, 965-979. 
Figure 1: Conceptual research framework.

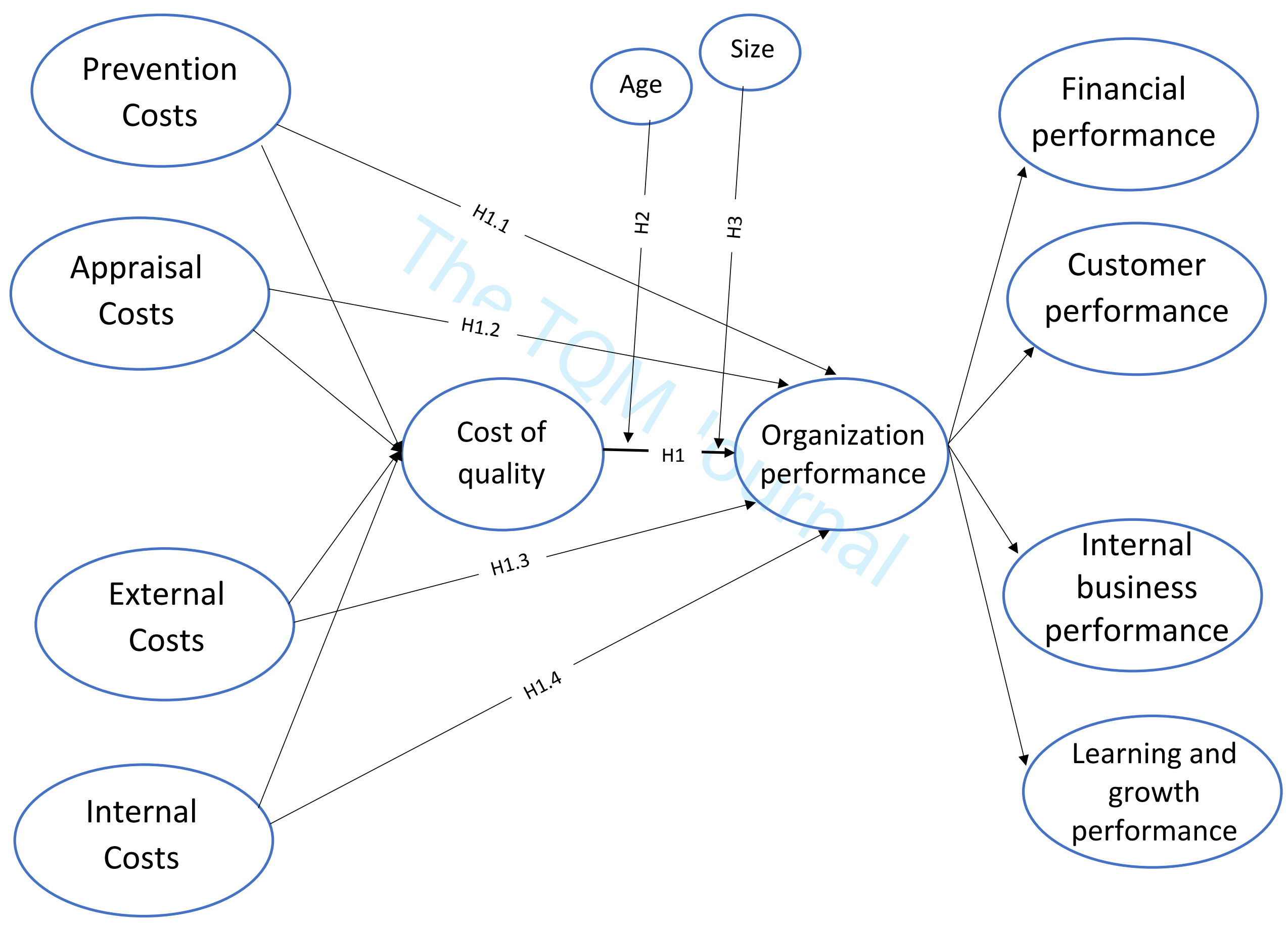




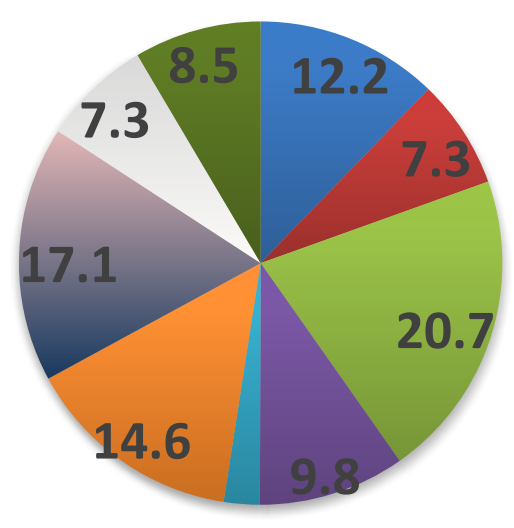

\section{4}

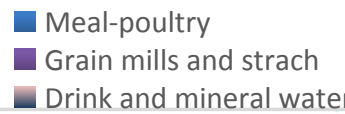

Meal-poultry
Grain mills and strach

Drink and mineral water

Oil and fat

Bread and bakery Agri-products and pasta
Dairy and milk

Sugar, confectionery and sweet Other

Figure 2: Distribution of companies sample according to business type. 


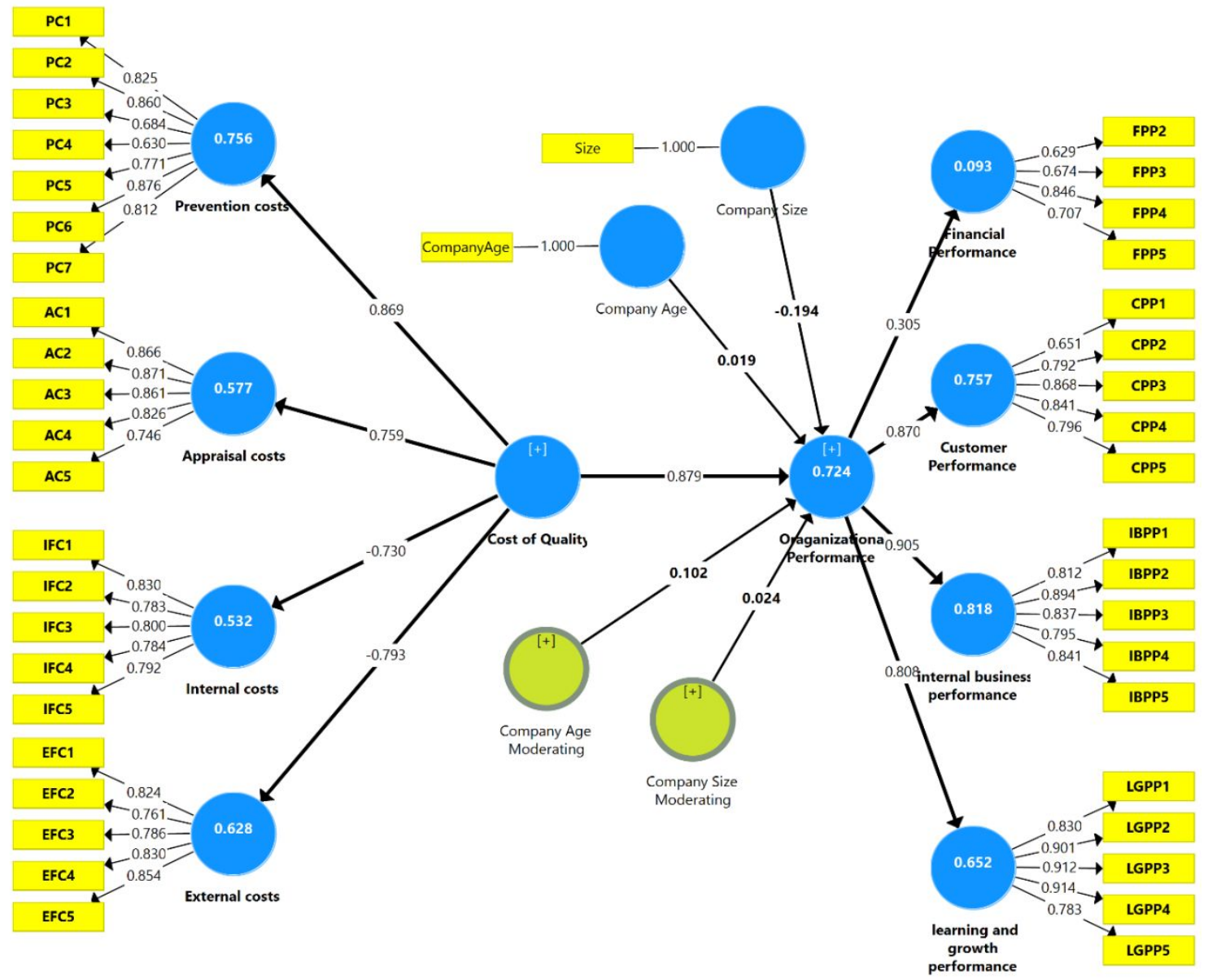

Figure 3: Measurement model evaluation as generated by SmartPLS. 


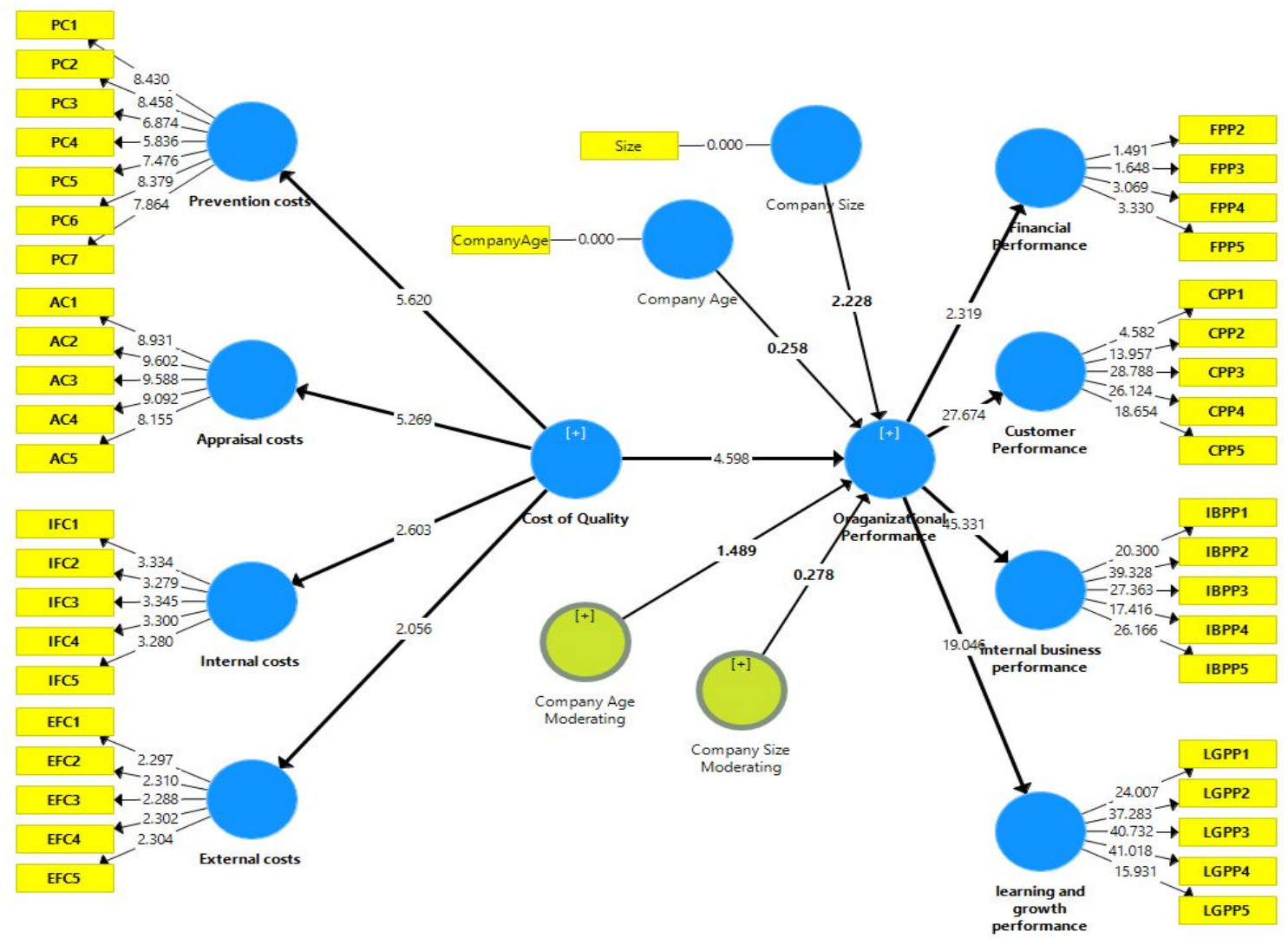

Figure 4: P-values generated by SmartPLS 
Table 1. Demographics of the sample

\begin{tabular}{|c|c|c|}
\hline Characteristic & Alternative & Percentage \\
\hline Job Title & $\begin{array}{l}\text { General manager } \\
\text { Quality manager } \\
\text { Quality engineer } \\
\text { HR manager }\end{array}$ & $\begin{array}{l}26.8 \% \\
32.9 \% \\
12.2 \% \\
28.1 \%\end{array}$ \\
\hline $\begin{array}{l}\text { Respondents' work experiences in } \\
\text { companies }\end{array}$ & $\begin{array}{l}0-5 \text { years } \\
6-10 \text { years } \\
11-15 \text { years } \\
16-20 \text { years } \\
\text { More than } 20 \text { years }\end{array}$ & $\begin{array}{l}18.3 \% \\
36.6 \% \\
28.8 \% \\
13.4 \% \\
3.7 \%\end{array}$ \\
\hline Company ownership & $\begin{array}{l}\text { Family owned business } \\
\text { Non-family owned business }\end{array}$ & $\begin{array}{l}61.9 \% \\
39 \%\end{array}$ \\
\hline Company working years & $\begin{array}{l}0-5 \text { years } \\
11-15 \text { years } \\
16-20 \text { years }\end{array}$ & $\begin{array}{l}12.2 \% \\
45.1 \% \\
23.2 \%\end{array}$ \\
\hline Respondent company's size & $\begin{array}{l}\text { Micro enterprise } \\
\text { Small enterprise } \\
\text { Medium enterprise } \\
\text { Large enterprise }\end{array}$ & $\begin{array}{l}2.4 \% \\
13.4 \% \\
54.9 \% \\
29.3 \%\end{array}$ \\
\hline $\begin{array}{l}\text { Certifications of responding } \\
\text { companies }\end{array}$ & $\begin{array}{l}\text { Yes } \\
\text { No }\end{array}$ & $\begin{array}{l}65.9 \% \\
34.1 \%\end{array}$ \\
\hline
\end{tabular}


Table 2: Cronbach's Alpha and composite reliability values

\begin{tabular}{|l|c|c|c|}
\hline \multicolumn{1}{|c|}{ Construct } & Cronbach's Alpha & $\begin{array}{l}\text { Composite } \\
\text { Reliability }\end{array}$ & $\begin{array}{l}\text { Composite } \\
\text { Reliability }\end{array}$ \\
\hline $\begin{array}{l}\text { Customer } \\
\text { performance (CP) }\end{array}$ & 0.850 & 0.894 & Acceptable \\
\hline $\begin{array}{l}\text { Financial performance } \\
\text { (FP) }\end{array}$ & 0.712 & 0.809 & Acceptable \\
\hline $\begin{array}{l}\text { Internal business } \\
\text { performance (IP) }\end{array}$ & 0.892 & 0.921 & Acceptable \\
\hline $\begin{array}{l}\text { Learning and growth } \\
\text { performance (LGP) }\end{array}$ & 0.918 & 0.939 & Acceptable \\
\hline Appraisal costs (AC) & 0.891 & 0.920 & Acceptable \\
\hline $\begin{array}{l}\text { External failure costs } \\
\text { (EFC) }\end{array}$ & 0.870 & 0.906 & Acceptable \\
\hline $\begin{array}{l}\text { Internal failure costs } \\
\text { (IFC) }\end{array}$ & 0.858 & 0.898 & Acceptable \\
\hline Prevention costs (PC) & 0.893 & 0.917 & \\
\hline
\end{tabular}


Table 3 Main results - measurement model

\begin{tabular}{|c|c|c|c|c|c|}
\hline $\begin{array}{c}\text { First order } \\
\text { latent variable }\end{array}$ & Second order latent variable & $\begin{array}{l}\text { Manifest } \\
\text { variable }\end{array}$ & $\begin{array}{c}\text { Outer } \\
\text { Loading }\end{array}$ & AVE & CR \\
\hline \multirow[t]{22}{*}{ COQ } & \multirow[t]{7}{*}{ PC } & $\mathrm{PC} 1$ & 0.809 & \multirow[t]{7}{*}{0.614} & \multirow[t]{7}{*}{0.917} \\
\hline & & $\mathrm{PC} 2$ & 0.854 & & \\
\hline & & $\mathrm{PC} 3$ & 0.653 & & \\
\hline & & PC4 & 0.637 & & \\
\hline & & PC5 & 0.782 & & \\
\hline & & PC6 & 0.880 & & \\
\hline & & PC7 & 0.834 & & \\
\hline & \multirow{5}{*}{$\mathbf{A C}$} & $\mathrm{AC} 1$ & 0.856 & \multirow[t]{5}{*}{0.697} & \multirow[t]{5}{*}{0.920} \\
\hline & & $\mathrm{AC} 2$ & 0.858 & & \\
\hline & & $\mathrm{AC} 3$ & 0.860 & & \\
\hline & & $\mathrm{AC} 4$ & 0.835 & & \\
\hline & & $\mathrm{AC5}$ & 0.761 & & \\
\hline & \multirow{5}{*}{ IFC } & IC1 & 0.841 & \multirow[t]{5}{*}{0.637} & \multirow[t]{5}{*}{0.898} \\
\hline & & IC2 & 0.808 & & \\
\hline & & IC3 & 0.804 & & \\
\hline & & IC4 & 0.766 & & \\
\hline & & IC5 & 0.770 & & \\
\hline & \multirow{5}{*}{ EFC } & $\mathrm{EC} 1$ & 0.816 & \multirow[t]{5}{*}{0.658} & \multirow[t]{5}{*}{0.906} \\
\hline & & $\mathrm{EC} 2$ & 0.780 & & \\
\hline & & EC3 & 0.767 & & \\
\hline & & EC4 & 0.833 & & \\
\hline & & EC5 & 0.858 & & \\
\hline \multirow{13}{*}{$\begin{array}{c}\text { Organizational } \\
\text { Performance }\end{array}$} & \multirow{5}{*}{ FP } & FP1 & Deleted & \multirow[t]{5}{*}{0.517} & \multirow[t]{5}{*}{0.809} \\
\hline & & FP2 & 0.632 & & \\
\hline & & FP3 & 0.677 & & \\
\hline & & FP4 & 0.845 & & \\
\hline & & FP5 & 0.704 & & \\
\hline & \multirow{5}{*}{ CP } & CP1 & 0.651 & \multirow[t]{5}{*}{0.629} & \multirow[t]{5}{*}{0.894} \\
\hline & & CP2 & 0.792 & & \\
\hline & & $\mathrm{CP} 3$ & 0.868 & & \\
\hline & & CP4 & 0.841 & & \\
\hline & & CP5 & 0.795 & & \\
\hline & \multirow{3}{*}{ IP } & IP1 & 0.812 & \multirow[t]{3}{*}{0.700} & \multirow[t]{3}{*}{0.921} \\
\hline & & IP2 & 0.894 & & \\
\hline & & IP3 & 0.837 & & \\
\hline
\end{tabular}




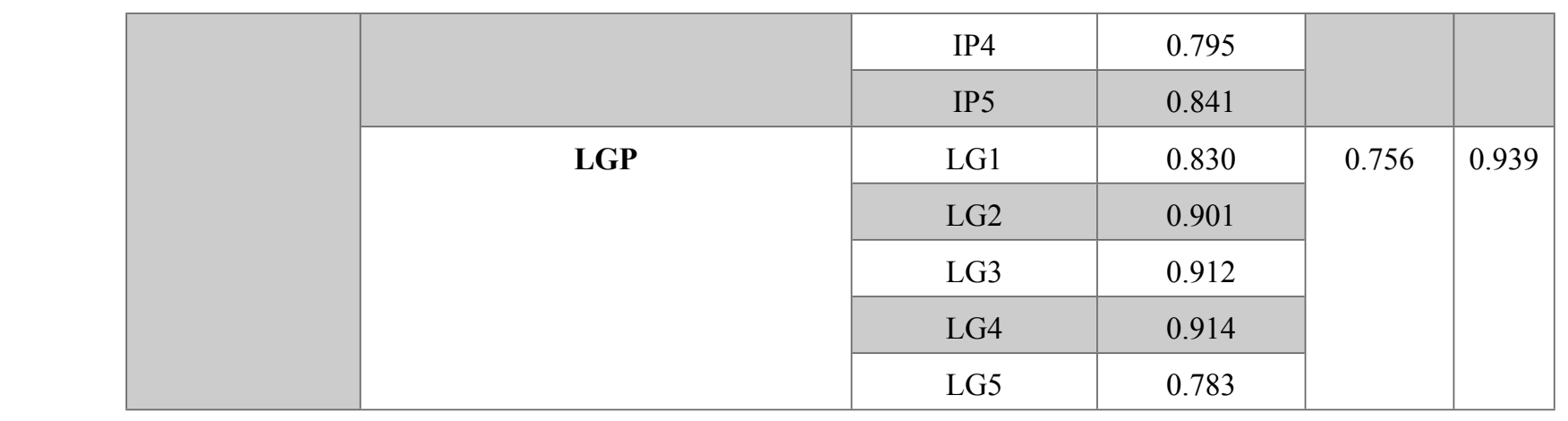

(n)


Table 4: Fornell-Larcker's criterion test summery.

\begin{tabular}{|l|r|r|r|r|r|l|l|l|}
\hline & \multicolumn{1}{|l|}{ AC } & PC & EFC & \multicolumn{1}{l|}{ FP } & IFC & CP & IP & LGP \\
\hline AC & $\mathbf{0 . 8 3 5}$ & & & & & & & \\
\hline PC & 0.459 & $\mathbf{0 . 7 9 3}$ & & & & & & \\
\hline EFC & -0.405 & -0.624 & $\mathbf{0 . 8 1 1}$ & & & & & \\
\hline FP & 0.200 & 0.205 & -0.063 & $\mathbf{0 . 7 1 9}$ & & & & \\
\hline IFC & -0.476 & -0.586 & 0.471 & -0.157 & $\mathbf{0 . 7 9 8}$ & & & \\
\hline CP & 0.545 & 0.654 & -0.626 & 0.344 & -0.456 & $\mathbf{0 . 7 8 3}$ & & \\
\hline IP & 0.504 & 0.771 & -0.596 & 0.178 & -0.573 & 0.647 & $\mathbf{0 . 8 3 7}$ & \\
\hline LGP & 0.437 & 0.508 & -0.596 & 0.206 & -0.538 & 0.562 & 0.577 & $\mathbf{0 . 8 7 0}$ \\
\hline
\end{tabular}


Table 5: Path Coefficients - Summary of Hypotheses Testing "Direct relationship"

\begin{tabular}{|c|c|c|c|c|c|c|}
\hline No & Hypotheses & $\begin{array}{l}\text { Std. } \\
\text { Beta }\end{array}$ & $\begin{array}{l}\text { Std. } \\
\text { Error }\end{array}$ & $\begin{array}{l}T- \\
\text { Value }\end{array}$ & $\begin{array}{l}P \text { - } \\
\text { Values }\end{array}$ & Decision \\
\hline$H 1$ & COQ -> Organizational Performance & 0.826 & 0.185 & 4.459 & 0.000 & Supported $* *$ \\
\hline H1.1 & $\begin{array}{l}\text { Prevention costs }->\text { Organizational } \\
\text { Performance }\end{array}$ & 0.372 & 0.097 & 3.812 & 0.000 & Supported $* *$ \\
\hline H1.2 & $\begin{array}{l}\text { Appraisal costs -> Organizational } \\
\text { Performance }\end{array}$ & 0.082 & 0.075 & 1.102 & 0.270 & Not Support \\
\hline H1.3 & $\begin{array}{l}\text { External costs -> Organizational } \\
\text { Performance }\end{array}$ & -0.278 & 0.094 & 2.939 & 0.003 & Supported $* *$ \\
\hline H1.4 & Internal costs -> Organizational Performance & -0.313 & 0.078 & 4.040 & 0.000 & Supported** \\
\hline $\mathrm{H} 2$ & $\begin{array}{l}\text { Company Age Moderating -> Organizational } \\
\text { Performance }\end{array}$ & 0.068 & 0.065 & 1.048 & 0.147 & Not Support \\
\hline H3 & $\begin{array}{l}\text { Company Size Moderating -> Organizational } \\
\text { Performance }\end{array}$ & 0.052 & 0.080 & 0.655 & 0.256 & Not Support \\
\hline
\end{tabular}


Table 6: The criteria of GOF

\begin{tabular}{|l|l|}
\hline GOF less than 0.1 & No fit \\
\hline GOF between 0.1 to 0.25 & Small \\
\hline GOF between 0.25 to 0.36 & Medium \\
\hline GOF greater than 0.36 & Large \\
\hline
\end{tabular}




\section{Appendix 1: Survey Instrument}

\section{Section 1: General information}

1. Name of your company

2. Please select the position you currently hold within your company.

- General Manager or CEO

- Quality manager

- Quality engineer

- HR manager

O Other, please specify.....

3. Please indicate the number of years that you have been in your current position.

○ 0 - 5 years.

○ 6 - 10 years.

- $11-15$ years.

- $16-20$ years.

- More than 20 years.

4. In what Food manufacturing is your company operating?

○ Meal-poultry

- Oils and fats

- Dairy and milk

- Grain mills and starch

- Bread and bakery

- Sugar, confectionery and sweet

- Drink and mineral water

- Agri-products and pasta

O Other, please specify

5. Is your company a family business?

○ Yes

○ No

6. Please indicate the number of years your company has been in food industry. (Number of years since your company was established).

○ 0 -5 years.

○ 6-10 years.

- 11-15 years.

- 16-20 years.

- More than 20 years

7. How do you classify your company size?

○ Micro enterprise (fewer than 10 employees).

- Small enterprises (10 to 49 employees).

- Medium-sized enterprise (50 to 249 employees).

○ Large enterprise (250 or more employees). 
8. In which governate your firm is located?

○ Bethlehem

○ Gaza

○ Hebron

○ Jenin

○ Jericho

○ Jerusalem

- Nablus

- Qalqilya

- Ramallah \& Al-Beireh

- Salfit

- Tubas

○ Tukaram

9. Does your company currently have any exporting activities?

- Yes

○ No

10. Does your company currently have any certifications (i.e., ISO certification)?

○ Yes (Please list names of classifications

o No

Section 2. To what extent does your company use the following cost of quality practices?

\begin{tabular}{|c|c|c|c|c|c|c|}
\hline NO. & Statement & 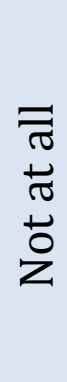 & 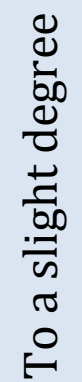 & 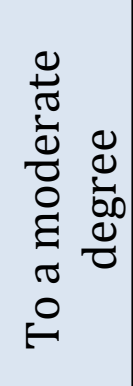 & 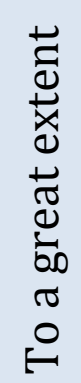 & 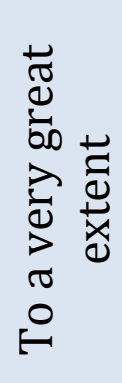 \\
\hline \multicolumn{7}{|c|}{ Part one: Prevention costs (PC) } \\
\hline 1. & $\begin{array}{l}\text { Your company sets a budget for staff } \\
\text { training }\end{array}$ & & & & & \\
\hline 2. & $\begin{array}{l}\text { Your company sets a budget for staff } \\
\text { development }\end{array}$ & & & & & \\
\hline
\end{tabular}




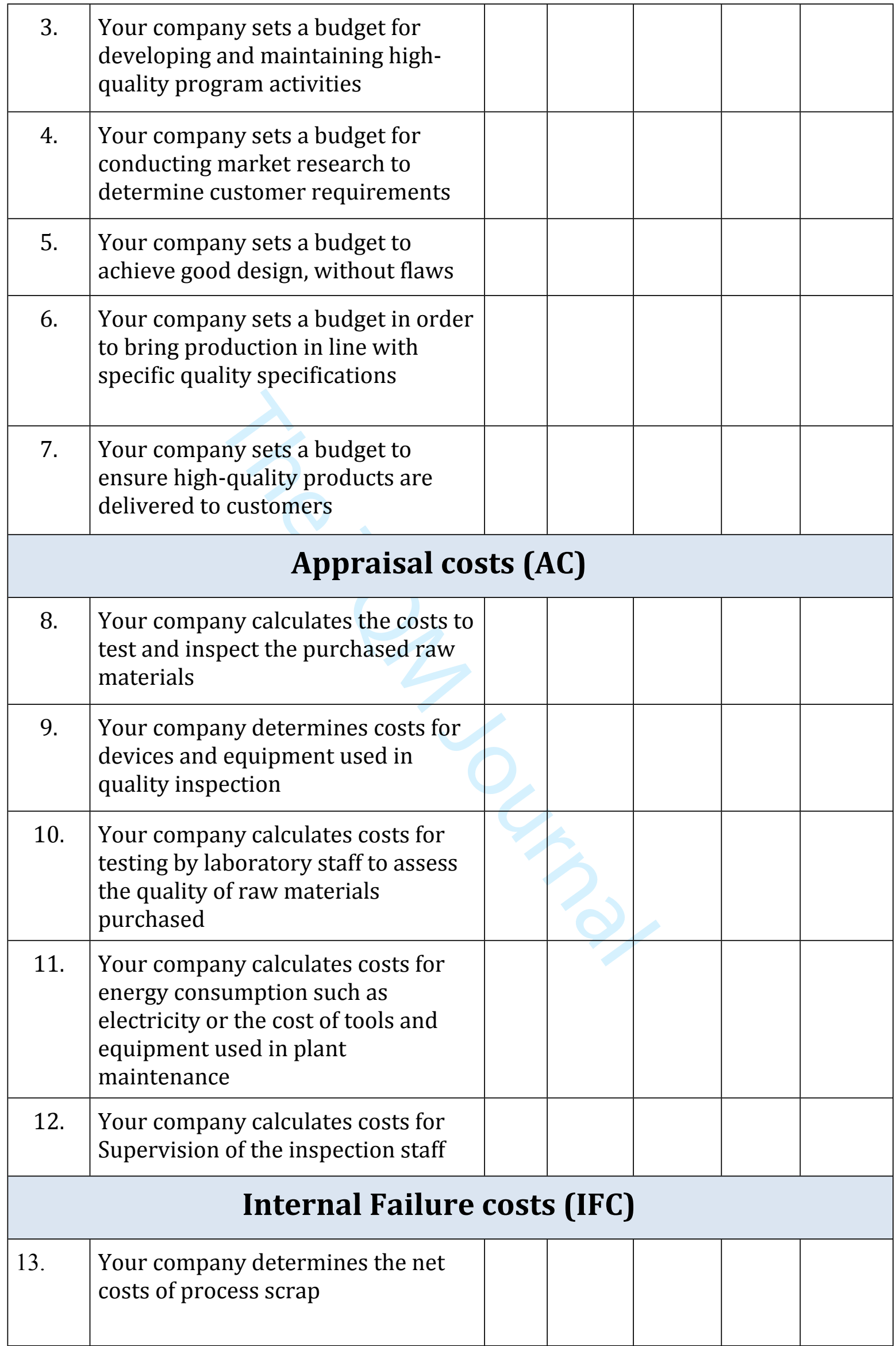




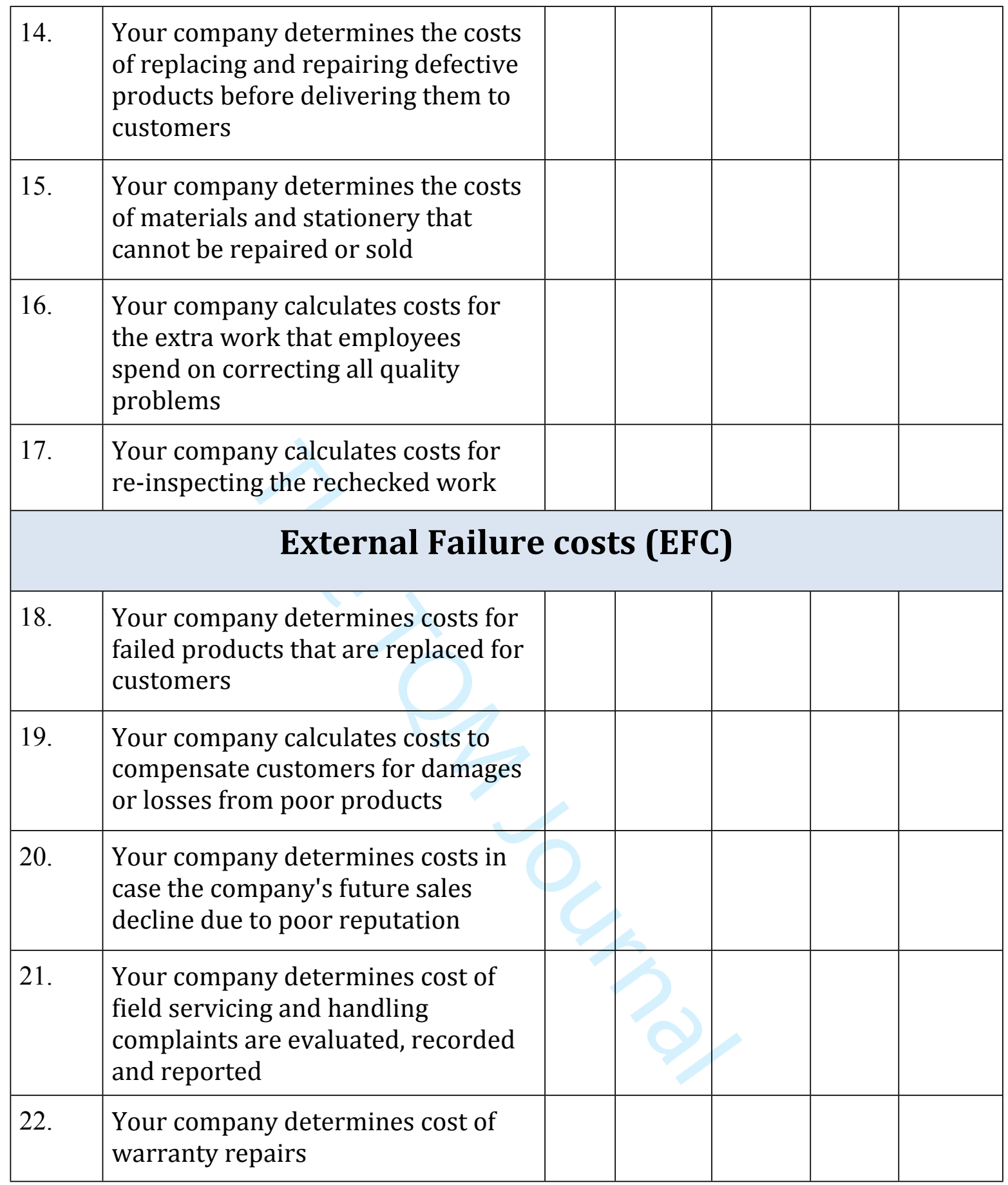

Section 3: Please show your level of agreement on the following statements. Please place a tick under the suitable choice: 


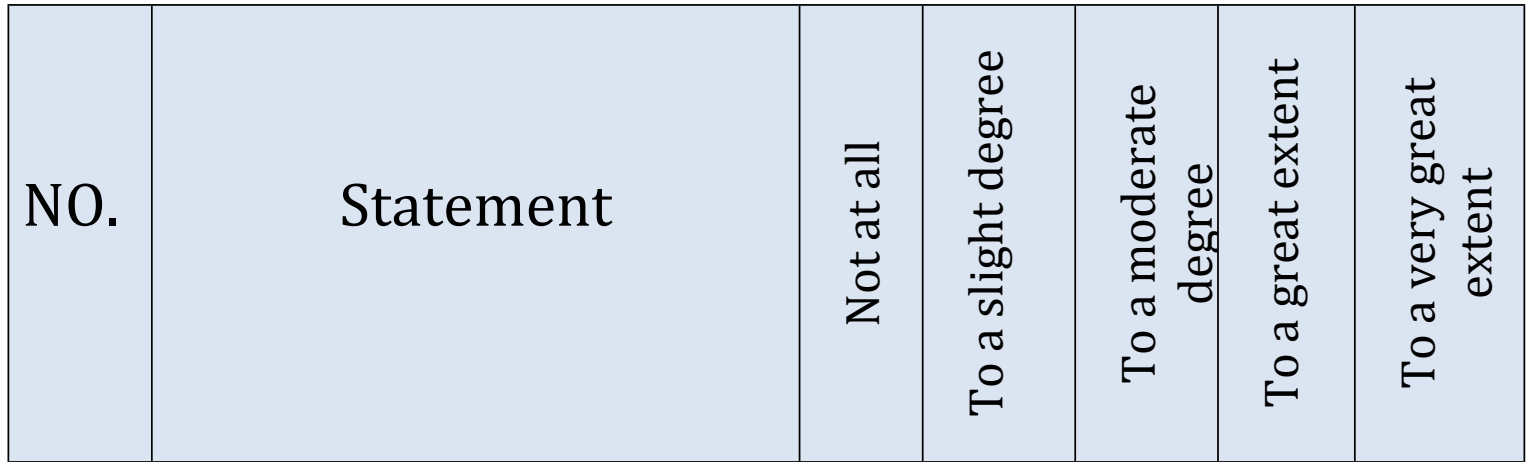

\section{Financial performance perspective}

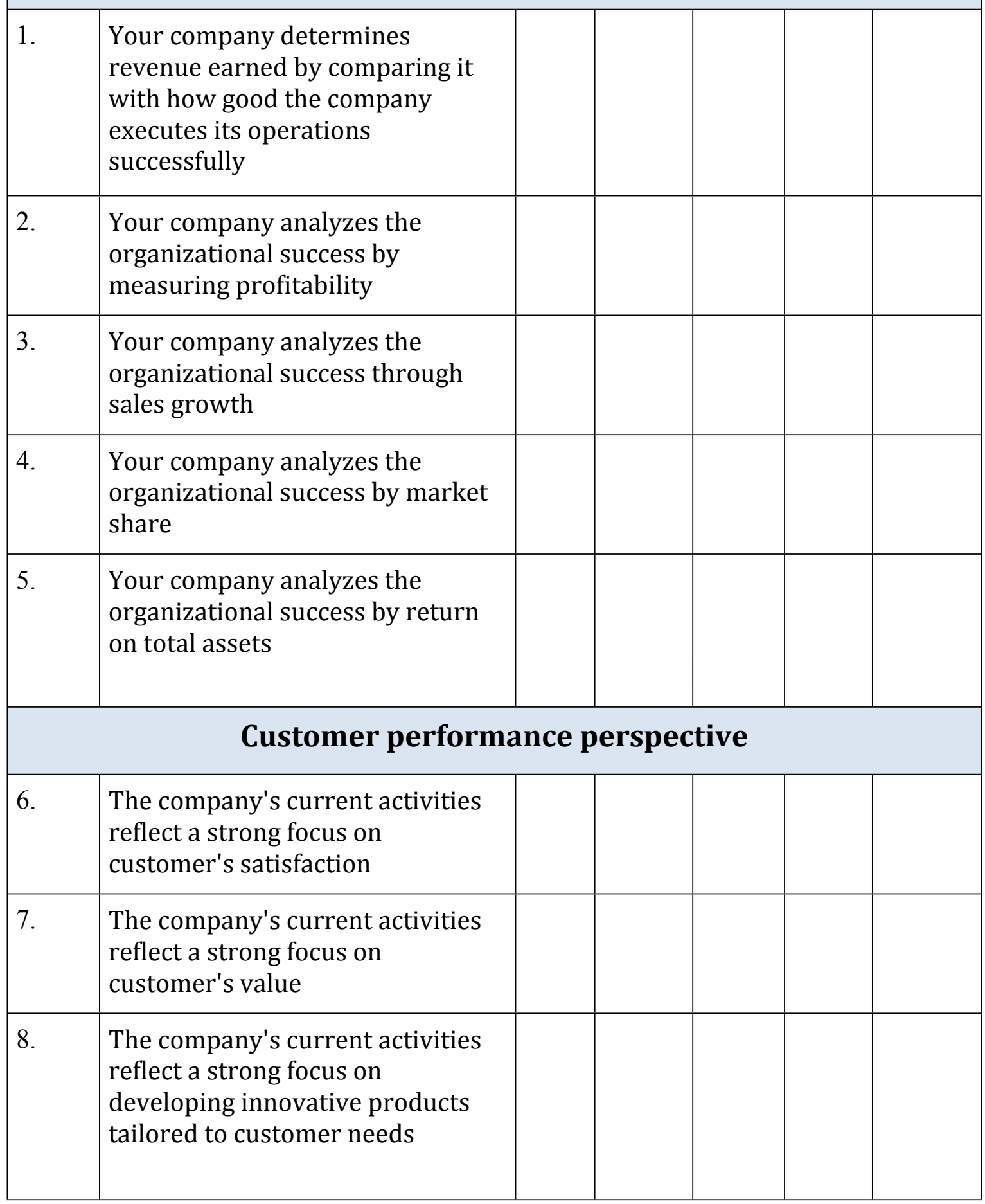




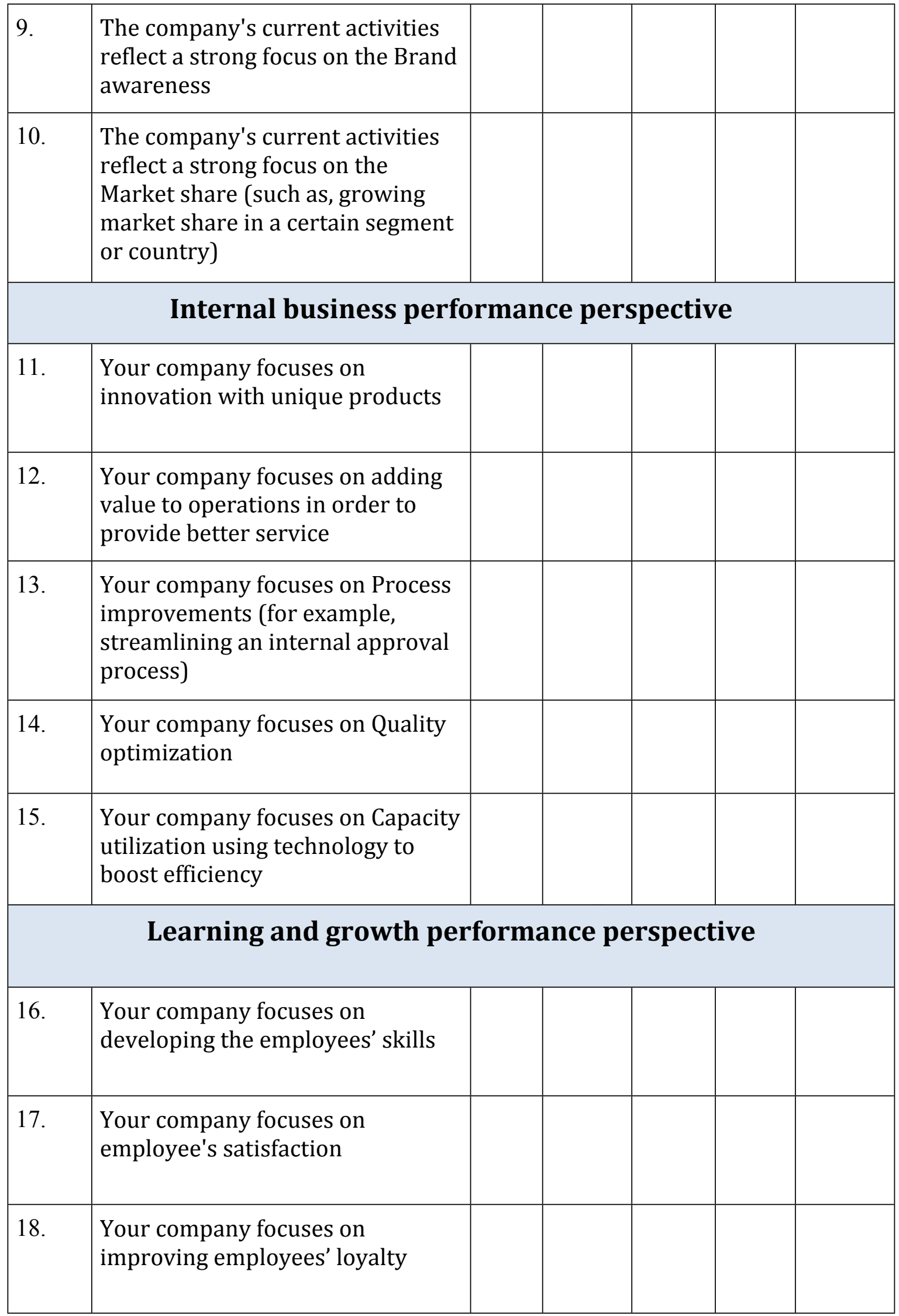




\begin{tabular}{|l|l|l|l|l|l|l|}
\hline 19. & $\begin{array}{l}\text { Your company focuses on } \\
\text { teamwork and knowledge } \\
\text { management }\end{array}$ & & & & & \\
\hline 20. & $\begin{array}{l}\text { Your company focuses on } \\
\text { databases, data protection } \\
\text { systems }\end{array}$ & & & & & \\
\hline
\end{tabular}

Section 4: Please use the text box below to add any further data or comments you would like to share with us. 